\title{
Perturbation of glycerol metabolism in hepatocytes from $n 3$-PUFA-depleted rats
}

\author{
LAURENCE PORTOIS $^{1}$, YING ZHANG ${ }^{2}$, LAURENCE LADRIÈRE ${ }^{3}$, JASON PERRET $^{4}$, \\ KARIM LOUCHAMI $^{2}$, NATHALIE GASPARD ${ }^{4}$, EMELINE HUPKENS ${ }^{2}$, NARGIS BOLAKY $^{4}$, \\ VALÉRIE DELFORGE ${ }^{1}$, RENAUD BEAUWENS ${ }^{5}$, WILLY J. MALAISSE ${ }^{2}$, \\ ABDULLAH SENER $^{2}$, YVON A. CARPENTIER ${ }^{1}$ and CHRISTINE DELPORTE ${ }^{4}$
}

\author{
Laboratories of ${ }^{1}$ Experimental Surgery L. Deloyers, ${ }^{2}$ Experimental Hormonology, ${ }^{3}$ Experimental Medicine, \\ ${ }^{4}$ Biological Chemistry and Nutrition, ${ }^{5}$ Cell and Molecular Physiology, Université Libre de Bruxelles, Brussels, Belgium
}

Received November 16, 2011; Accepted January 4, 2012

DOI: $10.3892 / \mathrm{ijmm} .2012 .943$

\begin{abstract}
Second generation $n 3$-PUFA-depleted rats represent a good animal model of metabolic syndrome as they display several features of the disease such as liver steatosis, visceral obesity and insulin resistance. The goal of our study was to investigate the influence of $n 3$-PUFA deficiency on hepatic glycerol metabolism. Aquaglyceroporin 9 (AQP9) allows hepatic glycerol transport and consequently contributes to neoglucogenesis. AQP9 knockout mice display hypertriacylglycerolemia, one of the hallmarks of the metabolic syndrome. Our data show reduced AQP9 expression at the protein level in $n 3$-PUFA-depleted rats, without any changes at the mRNA levels. [U- $\left.{ }^{14} \mathrm{C}\right]$ glycerol uptake was increased in hepatocytes from $n 3$-PUFA-depleted animal cells. The apparent discrepancy between decreased AQP9 protein expression, and increased $\left[\mathrm{U}-{ }^{14} \mathrm{C}\right]$ glycerol uptake could be explained by an observed increase in glycerol kinase activity.
\end{abstract}

\section{Introduction}

Metabolic syndrome is a common disease associated with an increased risk of type 2 diabetes, atherosclerosis and cardiovascular disease $(1,2)$. Its major characteristics include insulin resistance, dyslipidemia, abdominal obesity and hypertension $(1,2)$. Nutritional pattern plays an important role in the development and progression of the metabolic syndrome $(3,4)$. $\omega 3$ polyunsaturated fatty acids ( $n 3-P U F A)$ consumption may improve dyslipidemia and insulin resistance, and reduce adiposity, triacylglycerolemia, and retard the development of type 2 diabetes (5-7). Over the last 40-50 years, increased intake of $\omega 6$ polyunsaturated fatty acids (n6-PUFA) has

Correspondence to: Professor Christine Delporte, Laboratory of Biochemistry, CP 611, Université Libre de Bruxelles, Route de Lennik 808, B-1070 Brussels, Belgium

E-mail: cdelport@ulb.ac.be

Key words: glycerol metabolism, glycerol kinase, liver, aquaglyceroporin, metabolic syndrome, polyunsaturated fatty acids counterbalanced the decreased intake in $n 3$-PUFA in Western populations $(8,9)$.

Second generation $n 3-P U F A-d e p l e t e d$ rats display several features of the metabolic syndrome (10-14), making them a valuable model for metabolic syndrome.

Transmembrane glycerol transport is ensured by aquaglyceroporins belonging to the aquaporins (AQPs) family of water-permeable channel proteins accounting for transcellular water permeability in many organisms $(15,16)$. The aquaglyceroporins (AQP3, AQP7, AQP9, AQP10) are permeable to glycerol and urea in addition to water $(15,17,18)$. Regulation of AQP9 expression in hepatocytes participates in the control of glycerol metabolism during fasting and refeeding (19-22). AQP9-knockout animals are characterized by increased plasma glycerol and triacylglycerol levels (23).

The purpose of our study was to investigate the consequences of metabolic syndrome on glycerol metabolism using both control and second generation $n 3$-PUFA-depleted rats.

\section{Materials and methods}

Animals. Female control and second generation $n 3$-PUFAdepleted rats were 22 weeks of age. The $n 3$-PUFA-depleted rats were prepared as previously described $(12,13)$. Rats were given access to water and food ad libitum (either control or $n 3$-PUFAdepleted). The fatty acid pattern of lipids in the diets offered to control animals and $n 3$-PUFA-depleted rats was previously reported (12). Liver tissue was removed following euthanasia in a $\mathrm{CO}_{2}$ chamber. All animal experiments were conducted in compliance with the Institutional Animal Care and Use Committee.

$\omega 3$ fatty acids pattern in liver tissue. The methods used to measure the fatty acid content and pattern in total lipids from liver tissue has been previously described (24). 13 fatty acid content was determined on liver triglycerides and phospholipids from both control and $n 3$-PUFA-depleted rats and expressed as $\mu \mathrm{g} / \mathrm{mg}$ of tissue.

Real-time RT-PCR. Real-time RT-PCR analyses were performed as previously described (25). Primer sequences are shown in 
Table I. qRT-PCR primer sequences and efficiency.

\begin{tabular}{|c|c|c|c|}
\hline Gene & Sequence of primers & Amplicons (bp) & Efficiency \\
\hline AQP9 & $\begin{array}{l}\text { Sense: CGGAAAACTGCTCGTCGTAG } \\
\text { Antisense: CACCCAGGTTTCTGGAGTCA }\end{array}$ & 161 & $1.00 \pm 0.02$ \\
\hline Arbp & $\begin{array}{l}\text { Sense: GAGGTGCTGGACATCACAGA } \\
\text { Antisense: AGACAAAGCCAGGACCCTTT }\end{array}$ & 153 & $0.96 \pm 0.06$ \\
\hline PpiA & $\begin{array}{l}\text { Sense: GGGTTCCTCCTTTCACAGAA } \\
\text { Antisense: TCCCAGGACCTGTATGCTTC }\end{array}$ & 143 & $1.00 \pm 0.02$ \\
\hline$\beta$-actin & $\begin{array}{l}\text { Sense: GGGTTACGCGCTCCCTCATG } \\
\text { Antisense: CCACGCTCGGTCAGGATCTTC }\end{array}$ & 90 & $1.01 \pm 0.03$ \\
\hline RPL & $\begin{array}{l}\text { Sense: AGGCACCAGTCGGACCGATA } \\
\text { Antisense: GAAGCCGCTAGGCAGCATGT }\end{array}$ & 159 & $1.00 \pm 0.04$ \\
\hline
\end{tabular}

Efficiencies are expressed as mean $\pm \operatorname{SD}(n=3)$.

Table II. $\omega 3$ fatty acids pattern in liver triglycerides and phospholipids.

\begin{tabular}{|c|c|c|c|c|}
\hline \multirow[b]{2}{*}{ Rats } & \multicolumn{2}{|c|}{ Triglycerides } & \multicolumn{2}{|c|}{ Phospholipids } \\
\hline & Control & n3-PUFA-d & Control & n3-PUFA-d \\
\hline $\mathrm{C} 18: 3 \omega 3$ & $144.60 \pm 9.20$ & $\mathrm{ND}^{\mathrm{a}}$ & $42.84 \pm 2.86$ & $\mathrm{ND}^{\mathrm{a}}$ \\
\hline $\mathrm{C} 18: 4 \omega 3$ & ND & ND & ND & ND \\
\hline $\mathrm{C} 20: 5 \omega 3$ & $57.54 \pm 3.91$ & $\mathrm{ND}^{\mathrm{a}}$ & $134.10 \pm 11.66$ & $\mathrm{ND}^{\mathrm{a}}$ \\
\hline $\mathrm{C} 22: 3 \omega 3$ & ND & ND & ND & ND \\
\hline $\mathrm{C} 22: 5 \omega 3$ & $125.60 \pm 10.76$ & $\mathrm{ND}^{\mathrm{a}}$ & $381.00 \pm 16.66$ & $40.94 \pm 1.47^{\mathrm{a}}$ \\
\hline $\mathrm{C} 22: 6 \omega 3$ & $346.40 \pm 36.62$ & $\mathrm{ND}^{\mathrm{a}}$ & $4162.00 \pm 156.50$ & $368.10 \pm 11.63^{\mathrm{a}}$ \\
\hline
\end{tabular}

Table I. Out of seven housekeeping genes tested, the most stable were PpiA, Arbp, RPL and $\beta$-actin.

Western blot analysis. Crude plasma membrane protein preparation and Western blot analysis were performed as previously described (25). Proteins were immunolabeled using an affinitypurified antibody to AQP9 at a 1:500 dilution (Alomone, Jerusalem, Israel).

Hepatocyte isolation. Hepatocytes were isolated from overnight-starved control and $n 3$-PUFA-depleted rats according to the collagenase perfusion technique (26) slightly modified (27). Rats were anesthetized by intraperitoneal injection of Nembutal $(1.6 \mathrm{ml} / \mathrm{kg})$. Following abdominal incision, a catheter was introduced into the portal vein and ligated. The liver was successively perfused for 5 min with Hank's solution containing $0.5 \mathrm{mM}$ EDTA and $0.2 \%$ phenol red and then for $15 \mathrm{~min}$ with Hank's solution containing $5.0 \mathrm{mM} \mathrm{CaCl}$, $0.2 \%$ phenol red and $0.5 \mathrm{mg} / \mathrm{ml}$ type IV collagenase (SigmaAldrich, St. Louis, MO, USA). The liver was placed in a Petri dish containing Hank's solution prior to removal of the liver capsule and subsequent hepatocytes release. The obtained cellular suspension was filtered and the hepatocytes were washed three times by sedimentation-suspension in buffered bicarbonate and HEPES medium (28) containing $1.0 \mathrm{mg} / \mathrm{ml}$ bovine serum albumin. Cell viability was estimated by cell count following trypan blue staining.

Glycerol uptake in hepatocytes. Glycerol uptake (29) was performed in a $1.5 \mathrm{ml}$ microfuge tube using $\sim 60 \times 10^{3}$ isolated hepatocytes that were incubated at $37^{\circ} \mathrm{C}$ for $1-20 \mathrm{~min}$ in $0.12 \mathrm{ml}$ Krebs-Ringer bicarbonate buffer containing $0.2 \mathrm{mM}$ [U- $\left.{ }^{14} \mathrm{C}\right]$ glycerol $0.7 \mu \mathrm{Ci} / \mathrm{ml}$. At the end of incubation, the hepatocytes were separated by centrifugation at $5000 \mathrm{x} \mathrm{g}$ for 3 min following the addition of dibutylphthalate/ di-isononylphthalate (10:3) oils (Sigma-Aldrich, Steinheim, Germany). Cells were then mixed with $5 \mathrm{ml}$ scintillation liquid and the radioactivity was counted using a $\beta$-counter. Total glycerol uptake was calculated after correction for the blank value found under the same experimental conditions in the absence of hepatocytes. The extracellular space and total cellular water space were determined for each experiment using $2.0 \mathrm{mM} \mathrm{L-}\left[1-{ }^{14} \mathrm{C}\right]$ glucose $(0.38 \mu \mathrm{Ci} / \mathrm{ml})$ and $2.5 \mu \mathrm{Ci} / \mathrm{ml}$ ${ }^{3} \mathrm{HOH}$, respectively. 
Table III. Relative expression of AQP9 mRNA in liver tissue from $n 3$-PUFA-depleted rats and control rats.

Control rats
n3-PUFA-depleted rats

$100 \pm 12$
$115 \pm 8$

RNA extraction and qRT-PCR were performed as described in Materials and methods. AQP9 mRNAs was detected by qRT-PCR in liver tissue from $n 3$-PUFA-depleted rats $(\mathrm{n}=4)$ and control rats $(\mathrm{n}=4)$. The mRNA levels were first normalized using the normalization factor $(\mathrm{NF})$ determined by GeneNorm analysis of 4 housekeeping genes and then compared to the control samples set at 100\%. These normalized values $($ mean \pm SEM) are shown in the right column. Mann-Whitney tests were used to evaluate the statistical differences between the groups ( $>0.05$ ).

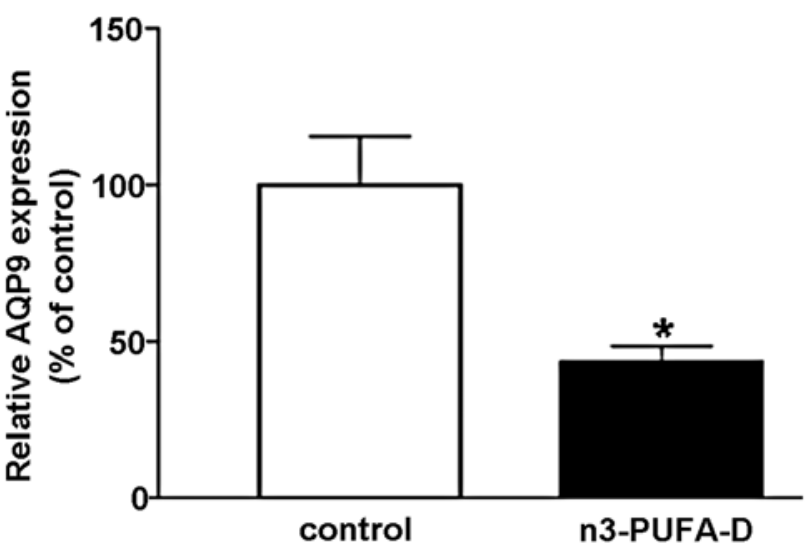

Figure 1. Relative hepatic AQP9 protein expression levels. Relative protein expression levels were determined as described in Material and methods. The results are expressed as the mean \pm SEM in percentage of control $(n=4$ in both animal groups). ${ }^{*}$ p $<0.05$ compared to control rats, Mann-Whitney test.

Determination of glycerol kinase activity. Glycerol kinase activity was measured by mixing $50 \mu \mathrm{l}$ of tissue homogenate $(10 \mathrm{mg}$ wet weight $/ \mathrm{ml})$ with $50 \mu \mathrm{l}$ of a reaction mixture containing $50 \mathrm{mM}$ Hepes- $\mathrm{NaOH}$ (pH 7.5), $6 \mathrm{mM} \mathrm{MgCl}_{2}, 60 \mathrm{mM}$ $\mathrm{KCl}, 10 \mathrm{mM} \mathrm{KH} \mathrm{PO}_{4}, 5 \mathrm{mM}$ ATP, $0.5 \mathrm{mM}$ or $25 \mathrm{mM}$ glycerol and $\left[\mathrm{U}-{ }^{14} \mathrm{C}\right]$ glycerol $(0.25 \mu \mathrm{Ci} / \mathrm{ml})$. After $30 \mathrm{~min}$ incubation at $37^{\circ} \mathrm{C}$, reaction was stopped by the addition of $1 \mathrm{ml}$ cold water, then phosphorylated product was separated by anion-exchange chromatography on AG1X8.

Statistical analysis. Data are expressed as the mean \pm SEM together with the number of separate determination (n) or degree of freedom (d.f.). Mann-Whitney U-test or Student t-test was used to evaluate the statistical differences between the groups. Covariance analysis was performed to determine regression coefficient. All statistical analyses were carried out using GraphPad InStat version 3.00 for Windows 95 (GraphPad Software, San Diego, CA, USA).

\section{Results}

$\omega 3$ fatty acid patterns in liver triglycerides and phospholipids. Determination of $\mathrm{n} 3$ fatty acid patterns showed significant decrease of $\mathrm{C} 18: 3 \omega 3, \mathrm{C} 20: 5 \omega 3, \mathrm{C} 22: 5 \omega 3$ and $\mathrm{C} 22: 6 \omega 3$ in both liver triglycerides and phospholipids from $n 3$-PUFA-depleted rats as compared to control animals ( $\mathrm{p}<0.0001$, Table II). The

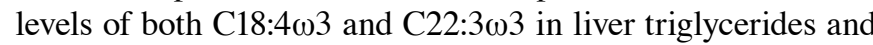

Table IV. Distribution spaces in hepatocytes.

\begin{tabular}{lcr}
\hline & $\begin{array}{c}\text { Control } \\
\text { rats }\end{array}$ & $\begin{array}{c}\text { n3-PUFA-D } \\
\text { rats }\end{array}$ \\
\hline${ }^{3} \mathrm{HOH}$ & $4.01 \pm 0.59(15)$ & $3.97 \pm 0.59(15)$ \\
$\mathrm{L}-\left[1-{ }^{14} \mathrm{C}\right]$ glucose & $1.40 \pm 0.51(15)$ & $2.27 \pm 0.30(15)$ \\
{$\left[\mathrm{U}-{ }^{14} \mathrm{C}\right]$ glycerol } & $28.95 \pm 2.76(19)$ & $54.26 \pm 7.26(19)$ \\
Intracellular ${ }^{3} \mathrm{HOH}$ & $2.62 \pm 0.29(15)$ & $1.70 \pm 0.37(15)$ \\
Intracellular $\left[\mathrm{U}-{ }^{14} \mathrm{C}\right]$ glycerol & $27.55 \pm 3.14(32)^{\mathrm{a}}$ & $52.00 \pm 8.20(32)^{\mathrm{a}}$ \\
\hline
\end{tabular}

The distribution spaces are the mean \pm SEM and are expressed as $\mathrm{nl} / 10^{3}$

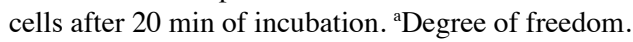

phospholipids from both control and $n 3$-PUFA-depleted rats were below the limit of detection (Table II).

Hepatic AQP9 expression. AQP9 mRNA levels in liver tissue from $n 3$-PUFA-depleted rats $(115 \pm 8 \%, \mathrm{n}=4)$ were not significantly different $(\mathrm{p}>0.05)$ from those of control rats $(100 \pm 12 \%$, $\mathrm{n}=4$ ) (Table III). However, the relative liver protein level of AQP9 was significantly decreased $(\mathrm{p}<0.05)$ in $n 3$-PUFAdepleted rats $(43.82 \pm 4.71 \%, n=4)$ compared to that of control rats $(100.00 \pm 15.68 \%, \mathrm{n}=4)$ (Fig. 1).

Hepatic $\left[U-{ }^{14}\right.$ C]glycerol uptake. After 20 min incubation, the mean value for the apparent distribution space of ${ }^{3} \mathrm{HOH}$ exceeded that of L- $\left[1-{ }^{14} \mathrm{C}\right]$ glucose in hepatocytes from both control animals and $n 3$-PUFA-depleted rats (Table IV). As judged from the paired differences between these two measurements, the mean value of the intracellular ${ }^{3} \mathrm{HOH}$ space, which failed to differ significantly in hepatocytes from control animal and $n 3$-PUFA-depleted rats, yielded an overall value of $2.16 \pm 0.25 \mathrm{nl} / 10^{3}$ cells $(\mathrm{n}=30, \mathrm{p}<0.001$ versus zero).

After $20 \mathrm{~min}$ incubation, the apparent distribution space of [U_ ${ }^{14} \mathrm{C}$ ]glycerol $\left(28.95 \pm 2.76 \mathrm{nl} / 10^{3}\right.$ cells; $\left.\mathrm{n}=19\right)$ largely exceeded $(\mathrm{p}<0.001)$ that of $\mathrm{L}-\left[1-^{14} \mathrm{C}\right]$ glucose $\left(1.40 \pm 0.51 \mathrm{nl} / 10^{3}\right.$ cells; $\left.\mathrm{n}=15\right)$ in hepatocytes from control rats (Table IV), yielding an intracellular glycerol apparent content of $5.51 \pm 0.63 \mathrm{pmol} / 10^{3}$ cells (d.f.=32). A comparable situation prevailed in the hepatocytes from $n 3$-PUFA-depleted animals, except that the apparent glycerol content was almost twice higher $\left(10.40 \pm 1.64 \mathrm{pmol} / 10^{3}\right.$ cells, d.f. $=32, \mathrm{p}<0.008)$ than in control animals.

The apparent glycerol content of hepatocytes was converted to an intracellular concentration, taking into account the intracellular ${ }^{3} \mathrm{HOH}$ space. The intracellular glycerol concentration 
Table V. Hepatic glycerol kinase activity.

Glycerol kinase activity (nmol/mg wet weight tissue per min)

Glycerol concentration (mM)

Control rats

$0.061 \pm 0.003$

$58.283 \pm 3.022$ $n 3-P U F A-D$ rats

$0.072 \pm 0.001^{\mathrm{a}}$

$66.117 \pm 1.253^{\mathrm{a}}$

25.0

Glycerol kinase activity was determined in liver homogenates from n3-PUFA-depleted rats $(n=6)$ and control rats ( $n=6)$ at two glycerol substrate concentrations $(0.5$ and $25 \mathrm{mM})$. Glycerol kinase activity is the mean $\pm \mathrm{SEM}$ and is expressed as nmol/mg wet weight tissue per min . Student t-tests were used to evaluate the statistical differences between the groups. ${ }^{\mathrm{a}} \mathrm{p}<0.05$, compared to control rats.

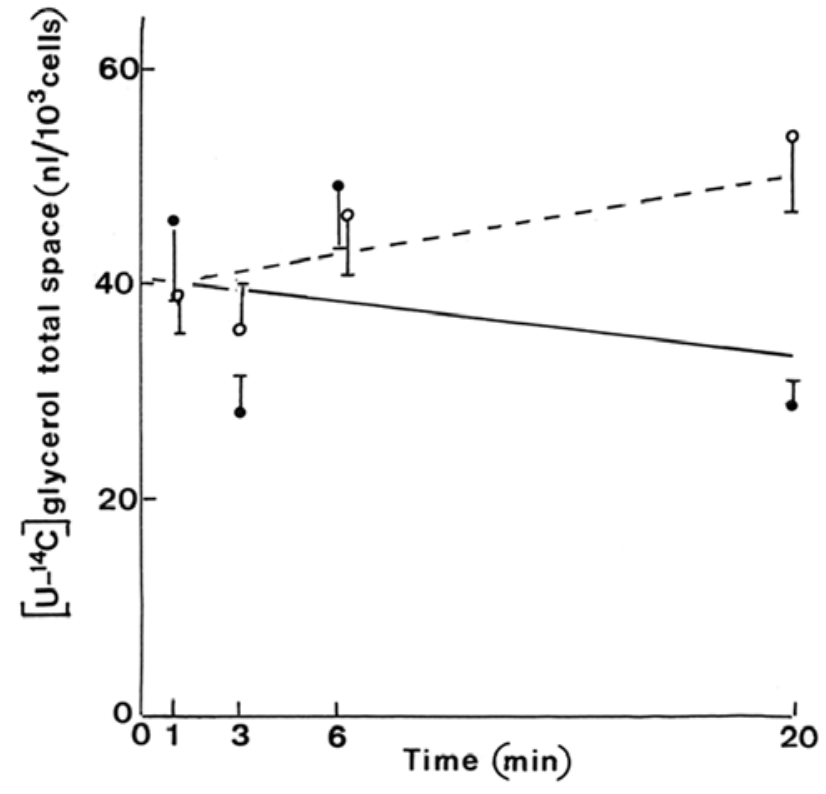

Figure 2. Time course of changes in the total apparent intracellular distribution space of $\left[\mathrm{U}-{ }^{14} \mathrm{C}\right] \mathrm{glycerol}$ in hepatocytes. Values for control animals (closed circles and solid line) or $n 3$-PUFA-depleted rats (open circle and dashed line) are displayed. The lines were obtained by regression analysis. Mean values \pm SEM are derived from 19-20 separate measurements collected in experiments using 4 rats from each group in each case.

of hepatocytes from $n 3$-PUFA-depleted rats $(6.13 \pm 1.69 \mathrm{mM}$, d.f.=46) was almost 3 -fold higher than that found in control animals $(2.10 \pm 0.39 \mathrm{mM}$, d.f. $=46, \mathrm{p}<0.025)$. Even the latter value was about 10 -fold higher $(\mathrm{p}<0.001)$ than the extracellular concentration of glycerol $(0.20 \mathrm{mM})$.

Net $\left[\mathrm{U}-{ }^{14} \mathrm{C}\right]$ glycerol uptake time course was investigated by incubating the hepatocytes for 1, 3,6 and $20 \mathrm{~min}$ in the presence of $\left[\mathrm{U}-{ }^{14} \mathrm{C}\right]$ glycerol. In the hepatocytes from control animals, no significant correlation was found between the individual values for the total apparent distribution space of $\left[\mathrm{U}_{-}{ }^{14} \mathrm{C}\right] \mathrm{glycerol}$ and the length of incubation $(r=-0.2046 ; n=78)$ (Fig. 2). After short incubation periods (1,3 and $6 \mathrm{~min})$, the values recorded in the hepatocytes from $n 3$-PUFA-depleted rats were not significantly different $(\mathrm{p}>0.8)$ from those measured in control animals. They averaged in $n 3$-PUFA-depleted rats $102.5 \pm 7.4 \%(\mathrm{n}=59)$ of the mean corresponding values recorded at the time of the incubation in control rats $(100.0 \pm 7.4 \%, \mathrm{n}=59)$. However, in the hepatocytes of $n 3$-PUFA-depleted rats, a significant positive correlation ( $\mathrm{r}=$ $+0.2699 ; n=78 ; \mathrm{p}<0.05$ ) was observed between the individual values for the total apparent distribution space of $\left[\mathrm{U}-{ }^{14} \mathrm{C}\right] \mathrm{glycerol}$ and the length of incubation. Covariance analysis, confirmed that the regression coefficient for the time-related changes in the apparent distribution space of $\left[\mathrm{U}-{ }^{14} \mathrm{C}\right]$ glycerol, was vastly different $(\mathrm{p}<0.001)$ in the hepatocytes from $n 3$-PUFA-depleted rats $(+0.8866)$ compared to control animals $(-0.5984)$. The mean values eventually reached after $20 \mathrm{~min}$ incubation were significantly higher $(\mathrm{p}<0.009)$ in $n 3$-PUFA-depleted rats than in control animals. Even the overall mean value found in the hepatocytes from control animals $\left(38.01 \pm 2.45 \mathrm{nl} / 10^{3}\right.$ cells, $\left.\mathrm{n}=78\right)$ remained significantly lower $(\mathrm{p}<0.01)$ than that found after 20 min incubation in the hepatocytes from $n 3$-PUFA-depleted rats $\left(54.26 \pm 7.26 \mathrm{nl} / 10^{3}\right.$ cells, $\left.\mathrm{n}=19\right)$ (Table IV).

Hepatic glycerol kinase activity. Hepatic glycerol kinase is known to display a double $\mathrm{Km}$ for glycerol: one of $25 \mu \mathrm{M}$ and one of $2.5 \mathrm{mM}$ (30-33). Therefore, glycerol kinase activity was measured using 0.5 and $25 \mathrm{mM}$ glycerol. At both glycerol concentrations, glycerol kinase activity was significantly higher in liver homogenates from $n 3$-PUFA-depleted rats than in control rats (Table V).

\section{Discussion}

The effect of $n 3$-PUFA depletion was clearly observed in both liver triglycerides and phospholipids. Indeed, liver triglycerides and phospholipids from $n 3$-PUFA-depleted rats exhibited $\mathrm{C} 18: 3 \omega 3, \mathrm{C} 20: 5 \omega 3, \mathrm{C} 22: 5 \omega 3$ and $\mathrm{C} 22: 6 \omega 3$ levels much lower to those observed in control rats, while $\mathrm{C} 18: 4 \omega 3$ and $\mathrm{C} 22: 3 \omega 3$ levels were undetectable in liver triglycerides and phospholipids from both control and $n 3$-PUFA-depleted rats.

Aquaglyceroporins account for cellular glycerol transport. Our data indicate reduced hepatic AQP9 protein expression in $n 3$-PUFA-depleted rats compared to control rats. However, no difference was detected between the relative AQP9 mRNA levels in liver from $n 3$-PUFA-depleted compared to control animals. This was somehow unexpected as insulin is known to induce a down-regulation of AQP9 expression at the transcriptional level (34); and as PUFA-depleted rats furthermore suffer from chronic hyperinsulinemia (13). However, the reduced AQP9 protein expression could result from the insulin resistance concomitantly displayed by the $n 3$-PUFA-depleted rats, together with other features of metabolic syndrome. 
Finally, the levels of most proteins do not necessarily correlate with the levels of their transcripts (35). Therefore, the observed reduced AQP9 protein expression appears to result from a translational effect and/or modification of protein turnover, rather than from a transcriptional effect. Further studies will however be required to clarify this point.

Another non-insulin-dependent regulation of AQP9 could be related to nutritional cues. Indeed, $n 3$-PUFA bind to peroxisome proliferator-activated receptors (PPARs) $(36,37)$ and some aquaglyceroporin expression can be enhanced in response to PPAR $\gamma$ activation $(38,39)$. Consequently, the lack of effects of PPAR $\gamma$ activation, due to $n 3$-PUFA deficiency, might account for the absence of effect on AQP9 mRNA levels. Even thought the effects of $n 3$-PUFA on post-translational mechanisms are unknown, such mechanisms could be responsible for the reduction in AQP9 protein expression. Additional studies will be required to further clarify these possibilities.

Measurements of hepatic $\left[\mathrm{U}-{ }^{14} \mathrm{C}\right] \mathrm{glycerol}$ uptake also showed some differences between n3-PUFA-depleted and control rats. The faster $\left[\mathrm{U}-{ }^{14} \mathrm{C}\right]$ glycerol uptake by hepatocytes from $n 3$-PUFA-depleted rats resulted in a two-fold higher value in $n 3$-PUFA-depleted versus control rats after $20 \mathrm{~min}$ incubation. Such differences may reflect a higher rate of gluconeogenesis in $n 3$-PUFA-depleted rats versus normal animals, paralleling glucose intolerance and insulin resistance.

The apparent discrepancies between the decreased AQP9 protein level in $n 3$-PUFA-depleted rats and increased [U- $\left.-{ }^{14} \mathrm{C}\right]-$ glycerol uptake could be explained by intracellular glycerol metabolism. Indeed, in hepatocytes, insulin increases glucose uptake despite no change in GLUT-2 expression but merely because of increased glucose phosphorylation and incorporation into glycogen. GLUT-2 expression can be directly assessed by measuring the permeability using non-metabolized analogues, such as 3-O-methylglucose or deoxyglucose; unfortunately no such analogues exist for glycerol. Considering the large amount of glycerokinase activity in hepatocytes (40), glycerol metabolites may be generated in liver. Therefore, it is conceivable that the measured glycerol uptake reflects differences in intracellular metabolism rather than a modest modification of aquaglyceroporins expression at the cell membrane. This indeed seems to be the case as glycerol kinase activity, measured at substrate saturation for both $\mathrm{Km}$ of the enzyme, is significantly increased in $n 3$-PUFA-depleted rats compared to control rats.

In conclusion, $n 3$-PUFA-depleted rats exhibit decreased hepatic AQP9 protein levels, increased $\left[\mathrm{U}-{ }^{14} \mathrm{C}\right]$ glycerol uptake and increase glycerol kinase activity. Additional studies will be required to refine our understanding with respect to both the post-translational mechanisms regulating hepatic AQP9 protein, its cellular localisation, as well as the mechanisms controlling glycerol metabolism.

\section{Acknowledgements}

This work was supported by grants 3.4561.07 (to C.D.), 3.4502.09 (to C.D.), 3.4574 .07 (to Y.A.C.), and 3.4520.07 (to A.S.) from the Fund for Medical Scientific Research (FRSM, Belgium) and by a research grant from the Nutricia Research Foundation (no. 2007-E1 to C.D., The Hague, The Netherlands).

\section{References}

1. Jiamsripong P, Mookadam M, Honda T, Khandheria BK and Mookadam F: The metabolic syndrome and cardiovascular disease: Part I. Prev Cardiol 11: 155-161, 2008.

2. Alberti KGMM, Eckel RH, Grundy SM, Zimmet PZ, Cleeman JI, Donato KA, Fruchart JC, James WP, Loria CM and Smith SC Jr: Harmonizing the metabolic syndrome: a joint interim statement of the International Diabetes Federation Task Force on Epidemiology and Prevention; National Heart, Lung, and Blood Institute; American Heart Association; World Heart Federation; International Atherosclerosis Society; and International Association for the Study of Obesity. Circulation 120: 1640-1645, 2009.

3. Daram SR and Boppidi H: Nonalcoholic fatty liver disease: hepatic manifestation of obesity and the metabolic syndrome. Postgrad Med 120: E01-E07, 2008.

4. Roche HM, Phillips $\mathrm{C}$ and Gibney MJ: The metabolic syndrome: the crossroads of diet and genetics. Proc Nutr Soc 64: 371-377, 2005.

5. Carpentier YA, Portois L and Malaisse WJ: n-3 Fatty acids and the metabolic syndrome. Am J Clin Nutr 83: S1499-S1504, 2006.

6. Barre DE: The role of consumption of alpha-linolenic, eicosapentaenoic and docosahexaenoic acids in human metabolic syndrome and type 2 diabetes - a mini-review. J Oleo Sci 56: 319-325, 2007.

7. Lombardo YB, Hein $\mathrm{G}$ and Chicco A: Metabolic syndrome: effects of n-3 PUFAs on a model of dyslipidemia, insulin resistance and adiposity. Lipids 42: 427-437, 2007.

8. Benatti P, Peluso G, Nicolai R and Calvani M: Polyunsaturated fatty acids: biochemical, nutritional and epigenetic properties. J Am Coll Nutr 23: 281-302, 2004.

9. Simopoulos AP: The importance of the ratio of omega-6/omega-3 essential fatty acids. Biomed Pharmacother 56: 365-379, 2002.

10. Cancelas J, Prieto PG, Villanueva-Penacarrillo ML, Zhang Y, Portois L, Sener A, Carpentier YA, Valverde I and Malaisse WJ: Glucose intolerance associated to insulin resistance and increased insulin secretion in rats depleted in long-chain omega 3 fatty acids. Horm Metab Res 39: 823-825, 2007.

11. Armitage JA, Pearce AD, Sinclair AJ, Vingrys AJ, Weisinger RS and Weisinger HS: Increased blood pressure later in life may be associated with perinatal n-3 fatty acid deficiency. Lipids 38: 459-464, 2003.

12. Peltier S, Malaisse WJ, Portois L, Demaison L, Novel-Chate V, Chardigny JM, Sebedio JL, Carpentier YA and Leverve XM: Acute in vivo administration of a fish oil-containing emulsion improves post-ischemic cardiac function in n-3-depleted rats. Int J Mol Med 18: 741-749, 2006.

13. Oguzhan B, Zhang Y, Louchami K, Courtois P, Portois L, Chardigny JM, Malaisse WJ, Carpentier YA and Sener A: Pancreatic islet function in omega3 fatty acid-depleted rats: Glucose metabolism and nutrient-stimulated insulin release. Endocrine 29: 457-466, 2006.

14. Oguzhan B, Sancho V, Acitores A, Villanueva-Penacarrillo ML, Portois L, Chardigny JM, Sener A, Carpentier YA and Malaisse WJ: Alteration of adipocyte metabolism in omega3 fatty aciddepleted rats. Horm Metab Res 38: 789-798, 2006.

15. Agre P: Aquaporin water channels (Nobel Lecture). Angew Chem Int Ed Engl 43: 4278-4290, 2004.

16. Verkman AS: Novel roles of aquaporins revealed by phenotype analysis of knockout mice. Rev Physiol Biochem Pharmacol 155: 31-55, 2005.

17. Krane CM and Goldstein DL: Comparative functional analysis of aquaporins/glyceroporins in mammals and anurans. Mamm Genome 18: 452-462, 2007.

18. Rojek A, Praetorius J, Frokiaer J, Nielsen S and Fenton RA: A current view of the mammalian aquaglyceroporins. Annu Rev Physiol 70: 301-327, 2008.

19. Hibuse T, Maeda N, Nagasawa A and Funahashi T: Aquaporins and glycerol metabolism. Biochim Biophys Acta 1758: 1004-1011, 2006.

20. Maeda N, Funahashi T and Shimomura F: Metabolic impact of adipose and hepatic glycerol channels aquaporin 7 and aquaporin 9. Nat Clin Pract Endocrinol Metab 4: 627-634, 2008.

21. Verkman AS: Mammalian aquaporins: diverse physiological roles and potential clinical significance. Expert Rev Mol Med 10: e13, 2008

22. Maeda N, Hibuse T and Funahashi T: Role of aquaporin-7 and aquaporin-9 in glycerol metabolism; involvement in obesity. Handb Exp Pharmacol 190: 233-249, 2009. 
23. Rojek AM, Skowronski MT, Fuchtbauer EM, Fuchtbauer AC Fenton RA, Agre P, Frokiaer J and Nielsen S: Defective glycerol metabolism in aquaporin 9 (AQP9) knockout mice. Proc Natl Acad Sci USA 104: 3609-3614, 2007.

24. Simoens CH, Richelle M, Rössle C, Derluyn M, Deckelbaum RJ and Carpentier YA: Manipulation of tissue fatty acid profile by intravenous lipids in dogs. Clin Nutr 14: 177-185, 1995.

25. Soyfoo MS, De Vriese C, Debaix H, Martin-Martinez MD, Mathieu C, Devuyst O, Steinfeld SD and Delporte C: Modified aquaporin 5 expression and distribution in submandibular glands from NOD mice displaying autoimmune exocrinopathy. Arthritis Rheum 56: 2566-2574, 2007.

26. Seglen PO: Preparation of isolated rat liver cells. Methods Cell Biol 13: 29-83, 1976.

27. Liu GT, Zhang TM, Wang BE and Wang YW: Protective action of seven natural phenolic compounds against peroxidative damage to biomembranes. Biochem Pharmacol 43: 147-152, 1992.

28. Malaisse WJ: Alteration of pancreatic B-cell D-glucose metabolism in type-2 diabetes: The G quintet. Endocrinologia 40: 309-313, 1993 .

29. Sancho V, Trigo MV, Gonzalez N, Valverde I, Malaisse WJ and Villanueva-Penacarrillo ML: Effects of glucagon-like peptide-1 and exendins on kinase activity, glucose transport and lipid metabolism in adipocytes from normal and type-2 diabetic rats. J Mol Endocrinol 35: 27-38, 2005.

30. Yilmaz MT, Sener A and Malaisse WJ: Glycerol phosphorylation and oxidation in pancreatic islets. Mol Cell Endocrinol 52: 251-256, 1987.

31. Bublitz C and Wieland O: Glycerokinase. Meth Enzym 5: 354-361, 1962.
32. Barrera LA and Ho R: Adipose glycerol kinase: low molecular weight protein has two Michaelis constants for glycerol. Biochem Biophys Res Commun 86: 145-152, 1979.

33. Kanoh H and Ohno K: Partial purification and properties of diacylglycerol kinase from rat liver cytosol. Arch Biochem Biophys 209: 266-275, 1981.

34. Kuriyama H, Shimomura I, Kishida K, Kondo H, Furuyama N, Nishizawa H, Maeda N, Matsuda M,Nagaretani H,Kihara S, et al: Coordinated regulation of fat-specific and liver-specific glycerol channels, aquaporin adipose and aquaporin 9. Diabetes 51: 29152921, 2002

35. Foss EJ, Radulovic D, Shaffer SA, Goodlett DR, Kruglyak L and Bedalov A: Genetic variation shapes protein networks mainly through non-transcriptional mechanisms. PLoS Biol 9: e1001144, 2011.

36. Huwiler A and Pfeilschifter J: Lipids as targets for novel antiinflammatory therapies. Pharmacol Ther 124: 96-112, 2009.

37. Bordoni A, Di Nunzio M, Danesi F and Biagi PL: Polyunsaturated fatty acids: from diet to binding to PPARs and other nuclear receptors. Genes Nutr 1: 95-106, 2006.

38. Kishida K, Shimomura I, Kondo H, Kuriyama H, Makino Y, Nishizawa H, Maeda N, Matsuda M, Ouchi N, Kihara S, et al: Genomic structure and insulin-mediated repression of the aquaporin adipose (AQPap), adipose-specific glycerol channel. J Biol Chem 276: 36251-36260, 2001.

39. Jiang YJ, Kim P, Lu YF and Feingold KR: PPARgamma activators stimulate aquaporin 3 expression in keratinocytes/epidermis. Exp Dermatol 20: 595-599, 2011.

40. McGilvery RW: Biochemistry: A Functional Approach. W.B. Saunders Company, Philadelphia, PA, p344, 1970. 